\title{
Utility of Al models in critical care: union of man and the machine
}

\author{
Amos Lal ${ }^{1^{*}}\left(\mathbb{0}\right.$, Vitaly Herasevich ${ }^{2}$ id and Ognjen Gajic ${ }^{1}$
}

We read with great attention the remarkable Editorial by Vincent Liu highlighting the conundrums around the use of Artificial Intelligence (AI) in Critical Care [1]. Author appropriately highlighted various reasons for "cautious skepticism" around the use of this technology in the real world medicine; we wish to present a slightly more optimistic viewpoint.

We wholeheartedly agree with the author that the future AI platforms need to be conformed keeping in mind their applicability and end-user acceptance in mind. Amongst many challenges suffered by the current generation AI (Associative AI) models the 2 major issues are the "black-box" algorithms and the use of retrospective databases of EMR derivated clinical data points to refine and validate these models [2]. Due to these weaknesses the model provides prognostic information without any utility to change the outcome.

To counter these flaws, we have proposed in our preliminary work a concept of developing "Causal AI" models $[3,4]$. This platform which is based on directed acyclic graphs (DAGs) developed on real life understanding of biology and pathophysiology, provides additional level of accuracy and most importantly "actionable points of intervention" which could alter the clinical course of the patient. Additionally, the transparent analytics utilized in the development of our platform provides an additional measure of trust that we hope will translate to a better

*Correspondence: manavamos@gmail.com; Lal.Amos@mayo.edu

${ }^{1}$ Division of Pulmonary and Critical Care Medicine, Department of Medicine, Multidisciplinary Epidemiology and Translational Research in Intensive Care Group, Mayo Clinic, 200 1st St SW, Rochester, MN 55905, USA

Full list of author information is available at the end of the article acceptance by the end user, bedside clinicians and educators in this case.

Finally, we concur with utilizing the technology to "augment" our clinical decision making, cognitive training and education in the world of critical care medicine, instead of having "artificial" models that are inaccurate at best with limited clinical utility in real life. The future demands investing time and resources that will benefit our patients by improving safety and minimizing errors. Medical errors have been identified to be one of the leading causes of morbidity and mortality for our patients. Wouldn't it be nice if we could attempt our uncertain interventions in a virtual setting using "in-silico" models before exposing our patients to any inexact mediation? Utilization of digital twins for predictive modeling has been utilized successfully for clinical decision making adjunct, research and education in chronic diseases [5]. It is imperative for this technology to be further developed and utilized in the world of critical care. Directed research is also needed to define the metrics of performance for these models and maintaining transparency of analytics in the embedded algorithms.

\section{Acknowledgements \\ Not applicable.}

\section{Authors' contributions}

$\mathrm{AL}$ : conception of idea + manuscript draft + literature review + final review. $\mathrm{VH}$ : conception of idea + manuscript draft + literature review + final review. OG: conception of idea + manuscript draft + literature review + final review. All authors read and approved the final manuscript.

Funding

Not applicable.

Availability of supporting data Not applicable.

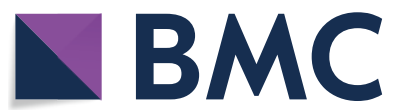

(c) The Author(s) 2021. This article is licensed under a Creative Commons Attribution 4.0 International License, which permits use, sharing, adaptation, distribution and reproduction in any medium or format, as long as you give appropriate credit to the original author(s) and the source, provide a link to the Creative Commons licence, and indicate if changes were made. The images or other third party material in this article are included in the article's Creative Commons licence, unless indicated otherwise in a credit line to the material. If material is not included in the article's Creative Commons licence and your intended use is not permitted by statutory regulation or exceeds the permitted use, you will need to obtain permission directly from the copyright holder. To view a copy of this licence, visit http://creativecommons.org/licenses/by/4.0/. The Creative Commons Public Domain Dedication waiver (http://creativecommons.org/publicdomain/zero/1.0/) applies to the data made available in this article, unless otherwise stated in a credit line to the data. 
Ethical approval and consent to participate

No IRB approval required.

\section{Consent for publication}

Not applicable.

\section{Competing interests}

The authors declare that they have no competing interests.

\section{Author details}

${ }^{1}$ Division of Pulmonary and Critical Care Medicine, Department of Medicine, Multidisciplinary Epidemiology and Translational Research in Intensive Care Group, Mayo Clinic, 200 1st St SW, Rochester, MN 55905, USA. ${ }^{2}$ Division of Critical Care, Department of Anesthesiology and Perioperative Medicine, Multidisciplinary Epidemiology and Translational Research in Intensive Care Group, Mayo Clinic, 200 1st St SW, Rochester, MN 55905, USA.

Received: 16 December 2020 Accepted: 25 January 2021

Published online: 02 February 2021

\section{References}

1. Liu VX. The future of Al in critical care is augmented, not artificial, intelligence. Crit Care. 2020;24(1):673.

2. Tomasev N, Glorot X, Rae JW, et al. A clinically applicable approach to continuous prediction of future acute kidney injury. Nature. 2019;572(7767):116-9.

3. Lal A, Pinevich Y, Gajic O, et al. Artificial intelligence and computer simulation models in critical illness. World J Crit Care Med. 2020;9(2):13-9.

4. Lal A LG, Cubro E, Chalmers S, Li H, Herasevich V, Yue D, Pickering B, Kilickaya O, Gajic O. Development and verification of a digital twin patient model to predict specific treatment response during the first 24 hours of sepsis. Crit Care Explor. 2020;Ahead of Print.

5. Eddy DM, Schlessinger L. Archimedes: a trial-validated model of diabetes. Diabetes Care. 2003;26(11):3093-101.

\section{Publisher's Note}

Springer Nature remains neutral with regard to jurisdictional claims in published maps and institutional affiliations.
Ready to submit your research? Choose BMC and benefit from:

- fast, convenient online submission

- thorough peer review by experienced researchers in your field

- rapid publication on acceptance

- support for research data, including large and complex data types

- gold Open Access which fosters wider collaboration and increased citations

- maximum visibility for your research: over $100 \mathrm{M}$ website views per year

At BMC, research is always in progress.

Learn more biomedcentral.com/submissions 